\title{
EARLY WARNING SIGNALS OF MILITARY COUPS
}

A Case Study of Montenegro

\section{INDIKÁTORY A SYSTÉMY VČASNÉHO VAROVÁNÍ PŘED VOJENSKÝM PUČEM}

\section{Případová studie Černé Hory}

Josef Kraus ${ }^{a}$

\begin{abstract}
Abstrakt
Tento text je zaměřen na identifikaci základních signálů, které by mohly varovat před vojenským pučem. Jeho hlavním smyslem je na bázi teoretického rámce vojenských pučů vymezit faktory, které zvyšují pravděpodobnost bližícího se a proběhnuvšího vojenského převratu $v$ zemi. Vytvořené schéma a seznam faktorů budou aplikovány $\checkmark$ rámci jednoprípadové studie na nedávný pokus o puč v Černé Hoře.
\end{abstract}

\section{Abstract}

The following paper focuses on the identification of basic early warning signals of military coups. The primary purpose is to use a theoretical framework of coups and create a list of factors that increase the probability of upcoming or ongoing military coups. This list will be applied to a case study of Montenegro, which recently experienced an attempt of overthrowing its government.

\section{Acknowledgements}

This paper was written as part of the research project SIVARBAL (Proposal of the system of indicators of early warning for possible crisis situations in the Balkans), funded by the Defence Research Programme of the Ministry of Defence of the Czech Republic.

\section{Klíčová slova}

Systém včasného varování; bezpečnostní indikátory; vojenský převrat; Černá Hora; násilí; predikce.

\section{Keywords}

Early Warning System; Security Indicators; Military Coup; Montenegro; Violence; Prediction.

a Katedra politologie, Fakulta sociálních studií, Masarykova univerzita. Email: jkraus@fss.muni.cz 


\section{INTRODUCTION}

Military coups are part of (not only) modern world politics and history. The role of an army in politics has been examined for decades. There are many concepts of armed forces being part of state governance of various kinds. Morris Janowitz ${ }^{1}$ identifies four different models of political-military elites - aristocratic, democratic, totalitarian, and garrison state. Apart from the model differences, military dictatorship can be prevented with proper settings of a democratic system observing, controlling and managing armed forces. The proper settings are the absolute and ideal point a democratic government can reach to fully control armed forces and prevent them from seizing power (or to interfere in state issues). In reality, many states have difficulties even to get closer to this highest standard, especially during the time of crisis or long-term problems of the state. Military coups or attempted military coups are still a highly topical issue of political and security research. The recent attempt in Montenegro has shown that armed forces are willing to seize power even in the European continent.

This paper deals with the topic of modern military coups and attempts with the main goal to identify the indicators leading to the situation when armed forces are willing to take action against a civil government. Examination of the indicators causing a higher probability of the attempt of a military coup would lead to the creation of an early warning system (EWS). With such a system, scholars, state authorities and non-state organizations can have a chance to identify the upcoming threat of a military coup attempt. Indicators or the early warning signals based on the developed EWS are often used in the spheres of intelligence, predictive analysis or prevention. There are many layers or levels for examination and identification of proper indicators leading to the detailed observation of the chosen topic. Also, from the perspective of methodology, many different approaches can be used. Various tools provide different outcomes and can be used for different kinds of research and analysis. A brief description and division can be found in the previous work of the author. ${ }^{2}$

First, the introduction to definitions of the military coup will be provided. After that, the analysis of different kind of typologies and definition attributes will follow with a special attention devoted to indicators signalizing an upcoming coup attempt. The background research of this topic is the relevant outcome of the following text with the final goal of creating a list of indicators to be used for the EWS formation. With such a framework, the paper continues to apply the EWS on the case of the coup attempt in Montenegro in 2016. The second half of the article has the form of a single case study, although with some limits based on the chosen case. The first limit is the coup did not happen after all; there was just a planned attempt exposed by the Montenegrin security forces. Second, there are many questions about the coup attempt. Some commentators and experts are even sceptical about the credibility of information

\footnotetext{
1 JANOWITZ, Morris. Armed Forces in Western Europe: Uniformity and Diversity, in European Journal of Sociology, Vol. 6, No. 2, Armed Forces and Society in Western Europe (1965), pp. 225237.

2 KRAUS Josef. Religious Extremism as a Cause of Armed Conflicts: Indicators and Early Warning Systems. Vojenské rozhledy. 2019, 28 (3), pp. 016-025.

ISSN 1210-3292 (print), 2336-2995 (on-line). Available at: https://bit.ly/2XO3UkN.
} 
provided by the Montenegrin security forces. There are conspiracy theories suggesting there was no such a plan at all. Detailed information and relevant data are difficult to obtain in this case. However, it is still possible to use it for the environment analysis and EWS application.

The data gathering for this article is focused on English written sources only. Although the author can read Serbian, Montenegrin and Russian sources, there is no need to use those. Official proclamations and data are available in English, which makes verification easier for the international audience. Other sources, such as books and expert articles used for the framework creation are also in English only.

\section{MiLitary Coups and Regime Changes}

Military coups have always been an important cause of a political regime change. During the $20^{\text {th }}$ century, we can examine dozens of military coups and multiple times more coup attempts not only in the "third world countries", but also in Europe. That is why many scholars and experts have analysed military coups from the perspective of their goals, types, conditions, process or their chance to succeed. Many theories deal with the involvement of armed forces in politics, trying to classify and evaluate these efforts as goals and causes. Such causes increase the probability of a military coup and also constitute the basis for developing the EWS.

Powel and Thyne $^{3}$ define a coup d'état as an irregular transfer of the state's chief executive, operated illegally by the military or other insider elites, which sometimes involves force or the threat of force, but need not involve casualties. Logically, the presence of armed forces is needed, if we speak about a military coup. Not only an army, but a wide range of armed forces can participate in a coup. According to Singh, ${ }^{4}$ a coup attempt is defined as an explicit action, involving some portion of the state military, police, or security forces, undertaken with the intent to overthrow the government. Quite often, there is a combination of different kinds of armed forces participating in a coup attempt.

On the other hand, the regime change takes place without the participation of masses, which distinguishes coups from revolutions. Galula, in his classical work, ${ }^{5}$ deals with the term "plot" as a synonym to a coup. A plot is a clandestine action of an insurgent group aiming to overthrow the top leadership in the respective country, it cannot and does not involve the masses, it is planned and prepared for a long time, but the action itself is brief and sudden.

A regime change with the participation of a military is quite common. Armed forces are usually one of (or the only) actors able to perform a coup due to their capacity, hierarchic structure and tradition of obeying orders from above. But the fact a military is capable of committing a coup does not mean it chooses to do so. There have to be reasons for armed forces to intervene in politics this way. Many scholars work with the

\footnotetext{
3 POWEL Jonathan M. and Clayton L. THYNE. 2011. Global Instances of Coups from 1950-2010:

A New Dataset. Journal of Peace Research 48(3). pp. 249-259.

${ }^{4}$ SINGH, Naunihal. 2016. Seizing Power: The Strategic Logic of Military Coups, Series: UPCC Book

Collections on Project MUSE. Baltimore, Maryland: Johns Hopkins University Press, p. 51

${ }^{5}$ GALULA, David. 1964. Counterinsurgency Warfare. New York: Frederick A. Praeger.
} 
motivation of a military to attempt a coup. The general view over this issue is that armed forces tend to venture into the political realm when their institutional interests are not being looked after or are jeopardized by the existing government. ${ }^{6}$ The argument is based on the premise the lower the defence budget is, the likelier coups become, and coups are least likely in states with high military spending. Putschist armies are also more often than not involved in a violent conflict, and disagree with the civilian leadership over the strategic and tactical responses. It might also be connected to a self-perception of a military as a social class or its inclination to a social class. On this broader perspective, not only economic demands are relevant, but also values in general. Where the latter's values are not aligned with those of the regime, officers may feel compelled to act on behalf of their social class. ${ }^{7}$

More than that, the preconditions and reasons for coups involve a combination of factors. Despite the military perspective, other theories explain the causes of a coup. Singh $^{8}$ brings five different sets of hypotheses for testing - economic, regime, social, strategic and military. Economic perspective deals with the questions of whether poor countries are more likely to experience coups and if trade openness affects the probability of a coup attempt so as to prevent low or negative economic growth. The regime perspective deals with the questions whether it is less likely to do a coup in countries with high popular support for a government or whether the political system (democracy, non-democracy, military rule) and election time matter. The social approach focuses on a difference between ethnically divided societies and homogenous ones with regard to the coup probability. The strategic set of hypotheses deals with coups happening on the background of the Cold War, superpowers competition or alliances and foreign interference. Finally, the military approach deals with the importance of armed forces in society and its effect on the coup probability. The relevance of the military constituting a larger part of society or the relevance of military spendings or history of successful and unsuccessful coup attempts are examined.

\section{CAuses of MiLitaRy COUPS}

The above-mentioned pattern is more or less reflected by other scholars. Especially economic and social issues are often repeated. The main idea connecting both of them is based on low performance of a state, signalizing incompetence or corruption, which either precede coups or are later used to justify them. As O'Kane ${ }^{9}$ argues, the preconditions of coups are a combination of factors, mainly economic ones, such as instability of the local economy, discrediting the government, and dependence of the economy on exports, making it vulnerable to outside shocks. Poorer countries, logically, do not have enough resources to control these problems, and the government is blamed for it. Therefore, O'Kane emphasizes, coups are unlikely to occur in a recently

\footnotetext{
${ }^{6}$ GAUB, Florence. 2016. Military coups: a very short introduction, European Institute for Foreign Studies, July 2016, Available at: https://bit.ly/2Uref3N

7 Ibid.

${ }^{8}$ SINGH, Ref. 5.

9 O'KANE, Rosemary. A Probabilistic Approach to the Causes of Coups D'Etat, British Journal of Political Science, Vol. 11, No. 3 (Jul., 1981), pp. 287-308.
} 
independent country until its new government has had the opportunity to demonstrate its inadequacy in dealing with the country's economy. It simply takes time for a government to lose support and for an opportunity for a coup to occur. The relevance of economy on conflicts and security is something widely discussed by two authors Paul Collier and Anke Hoeffler. ${ }^{10}$ Besides the famous greed and grievance theory, by examining coups in Africa, they identified the economic performance has an impact on potential plotters' willingness and ability to organize a coup. A weak economy makes military officers less satisfied with the political representation and more favourably disposed toward a coup attempt. Also, the economic performance affects the chances for a coup to succeed with high popular support, if the economy is devasted. While the government loses legitimacy due to its poor economic performance, suffers from a political crisis and fails to establish constructive civil-military relations, it is easier for the military to topple it. ${ }^{11}$ Egil Fossum ${ }^{12}$ counted that almost $2 / 3$ of all coups in Latin America took place at the time public disorders. The military tries to re-establish public order without further motives, or the disturbances may serve as a pretext to intervene when the real motives are completely different.

Other highly discussed factors affecting the probability of a coup attempt are regime types and civil society. Sudduth ${ }^{13}$ summarizes that citizens in stable democratic societies want to protect their electoral systems and will not support coups. Losing the support and lowering the chance of a successful coup, potential plotters are less likely to attempt a coup in democratic societies. On the other hand, military regimes have a higher risk of coups than other types of regimes, because they lack legitimacy and popular support, plus they are more vulnerable to internal divisions. According to some studies, the type of political system is not an important factor; its strength is. Strong autocracies and strong democracies experience the least political instability. Weak states will see more coups, political participation reduces the likelihood of coups, autocracies decrease the opportunities to initiate a coup because of effective coupproofing strategies. But some studies show strong democracies significantly reduce the chance that a country will experience a coup. A full democracy is about 12 times less likely to see a coup d'état compared with a dictatorship. ${ }^{14}$

The relation between the government and the military also matters from the perspective of interference in politics. Civilians increase the likelihood of a coup by politicizing the military. Any attempt to draw the armed forces into politics is a sign of weakness. Armed force in this matter can also play an important role in representing the will of the society and its values more than the government can. Military values such as discipline, bravery, obedience, honesty, and political impartiality are generally valued in society at large. Nationalism feeds this perception of a symbolic institution

${ }^{10}$ COLLIER, Paul and Anke HOEFFLER. 2005. Coup traps: Why does Africa have so many coups d'etat? Working paper, Centre for the Study of African Economies, Department of Economics, University of Oxford, Available at: https://bit.ly/2YoUHhl

${ }^{11}$ GAUB, Ref. 7.

12 FOSSUM, Egil. Factors Influencing the Occurrence of Military Coups D'Etat in Latin America, Journal of Peace Research, Vol. 4, No. 3 (1967), pp. 228-251.

${ }^{13}$ SUDDUTH, Jun Koga. Coup risk, coup-proofing and leader survival, Journal of Peace Research 2017, Vol. 54(1), pp. 3-15.

${ }^{14}$ BODEA, Christina, ELBADAWI, Ibrahim and Christian HOULE. Do Civil Wars, Coups and Riots Have the Same Structural Determinants?, International Interactions, 2017, VOL. 43, NO. 3, pp. 537-561. 
often called the "cradle of the state". Coups tend to take place in the context of a political crisis and when the armed forces believe they have a civilian mandate to resolve the turmoil. ${ }^{15}$

Political crises as well as military coups are very often present before, during and after elections (in "democracy-like" systems). There is a strong concentration of coup attempts in election years, as proven by Egil Fossum. ${ }^{16}$ He argues coups would be executed whether elections were being held or not, but the timing is what matters. Coups during the election year might occur for supervising the election or securing the transfer of power. The motive to prevent the coming to power of groups inimical to the military seems to be much more important. It is more a pre-emptive pre-election action, rather than reaction.

If a coup attempt happens, it raises the chance of another coup attempt in a nondistant future. Some analysis emphasizes the role of coup history on the probability of other attempts in the future. Singh ${ }^{17}$ proved in his study that countries having recent successful coups were more likely to have a coup attempt in the following year(s). The same findings are provided by Bodea (et al.), ${ }^{18}$ who argues that a country that experienced a coup in the past five years has more than doubled its risk of seeing another coup in the current year. Sudduth ${ }^{19}$ evolves this argumentation by the inverse proportionality - the more time has passed since the last coup attempt, the less likely it is that the country will experience another one.

The last but not least relevant factor affecting the probability of a coup attempt often mentioned in literature is the interference of foreign forces (armed or non-armed). Especially the presence of foreign troops, which, paradoxically, might have two different effects. On the one hand, it can be labelled as an important obstacle for a coup attempt. One of the most important strategies to prevent a coup or to neutralize the army in its effort to topple the government is to have foreign troops in the state's territory. Foreign troops will be particularly unlikely to be sympathetic to a coup attempt. But on the other hand, foreign countries might encourage coups, rather than hinder them. O'Kane ${ }^{20}$ argues that if the existing host government starts implementing policies that are against the interests of the foreign power, then the foreign army will have reason to intervene. The intervention is not specified in details, but except for the presence of foreign troops, the activity of secret services (covert operations, intelligence, etc.) might have a significant impact on local politics and a coup attempt as well.

\section{INDICATORS AND EWS OF A MILITARY COUP}

From the factors and arguments mentioned above, it is clear that the development of an EWS and a set of indicators based on the quantitative approach and data is very

\footnotetext{
${ }^{15}$ GAUB, Ref. 7.

${ }^{16}$ FOSSUM, Ref. 13.

17 SINGH, Ref. 5, p. 55

18 BODEA, ELBADAWI and HOULE, Ref. 15, p. 557.

19 SUDDUTH, Ref. 14, p. 11.

20 O’KANE, Ref. 10, p. 296.
} 
difficult or even impossible to achieve. There are some items to be followed, if a scholar, security institution or political sphere want to predict (and prevent) a military coup attempt. But still, it is very difficult to produce a list of indicators warning about the increasing probability of a military coup in the society. We are able to identify some dimensions to be followed and some phenomena to be watched, but not to make a list of indicators to be checked or not.

The crucial issues for the motivation of the military endeavour to topple the current government seem to be its relation with armed forces, the strength of the government and civil society and the government's legitimacy to rule, and the economic stability and performance of the country. These issues constitute the environment well-disposed or bad-disposed towards a coup attempt with dissatisfied society and the military. There are also secondary but still important issues such as regime type (connected to the factor of the government's strength), presence or intervention of foreign military forces, elections or a recent history of a successful coup attempt.

The strength of government (or governance) can be followed and evaluated by an external methodology of the state weakness and strength such as the Fragile State Index. ${ }^{21}$ If there is a noticeable and relevant regress in the statistics and database, it would be a clear sign of the state's weakening. Special attention might be paid to the economic performance of the state. Even though it is reflected by the Fragile State Index as well, focusing on economic problems might predict the lowering of the government credibility and the trust of armed forces in proper state leadership or defence of their financial interests. That might lead to dissatisfaction of this important part of society, willing to intervene in its or society's favour. A whole set of indicators of the state's economic performance can be used as a part of the EWS, GDP growth, unemployment rate, inflation, interest rate, balance of trade, government debt to GDP, etc. If there is an evident and long-term tendency of worsening (or a sudden dramatic fall) of these indicators, it should be evaluated as a signal of the higher potential of a coup attempt. In general, coups have been connected to political instability, as well as disrupted effectiveness of governance and changing incentives of leaders. ${ }^{22}$

Stable and strong civil society works as a prevention to coups, so where it is missing or disrupted, it can be considered a coup indicator. Another indicator related to governance and its resistance to coup attempts is the regime type. As we know, the probability of a coup is higher in the non-democratic regimes. So, the presence of a stable democracy can be perceived as prevention to coups, while the missing or weakening democracy is a warning signal. Logically, the presence of foreign military forces can affect a coup probability in two ways - to lower (prevent) it or to increase (cause or help) it. A history of a coup attempt in the last five years can play the role of a factor increasing the chance of another attempt. But just the record itself cannot be considered a signal of an upcoming coup d'etat. The same applies to elections. While it has been proved that during an election year the chances of a coup attempt are higher, this fact itself is not an indicator of an upcoming coup. It is more a factor affecting the pro-coup conditions rather than an indicator. But still, there is a reason to pay attention to elections taking part during the analysis of a coup probability.

${ }^{21}$ Available at: https: / / fragilestatesindex.org/

22 BODEA, ELBADAWI and HOULE, Ref. 15, p. 540. 


\section{COUP ATTEMPT IN MONTENEGRO}

A revealed coup d'état plot, planned and prepared in 2016, caused a significant earthquake in Montenegrin politics. On the background of the Montenegrin decision in December 2015 to join NATO and the Russian pressure to prevent it, Russia together with the local opposition and Serb ethno-nationalists coordinated an unsuccessful attempt to topple the democratically elected government of Montenegro in October 2016. On the day of Montenegro's 2016 parliamentary elections (held on $16^{\text {th }}$ October), the police in Podgorica detained former Serbian gendarmerie commander Bratislav Dikić and 19 other individuals on charges of forming a criminal organization with the intent to overthrow the government. Russian agents, Serbian extremists, and leaders of the Montenegrin opposition alliance (Democratic Front) were prepared to overthrow the government on the election night. They planned to initiate political violence with the hope of triggering nationwide protests that would bring the Democratic Party of Socialists government to its end. According to officials, Serbian nationals initiated the enterprise in early 2016 under the direction of Russian GRU and FSB operatives. ${ }^{23}$

This investigation theory was finally confirmed by a court verdict with two Russian intelligence officers and two opposition politicians among 13 people sentenced to jail in May 2019. The two Russian nationals were sentenced in absentia to prison for 15 and 12 years, respectively. According to the court, the main aims of putschists were to topple the Montenegro's government, to kill the prime minister and to bring a proRussian alliance to power. The two leaders of the Democratic Front, an opposition alliance that wants to depose Djukanović and seeks closer ties with Serbia and Russia, received five-year jail terms each. ${ }^{24}$

So, the coup attempt was unsuccessful and revealed before any action was taken. It would be a hypothetical question whether there was a chance for the coup to be successful or not. But the attempt itself is enough for the EWS testing.

\section{EWS AND THE MONTENEGRIN CASE}

If we look at the state and government strength in the case of Montenegro, according to the Fragile State Index, in 2016 the country was on the $131^{\text {st }}$ place out of 178 countries (higher number means higher stability of the state). From the set of indicators collected into the final score, the worst rating is noticeable in the case of indicators called Fractionalized Elites, Group Grievance and External Intervention. According to the FSI methodology, the Factionalized Elites indicator considers the fragmentation of state institutions along ethnic, class, clan, racial or religious lines, as well as brinksmanship and gridlock between ruling elites. The use of nationalistic political rhetoric by ruling elites, often in terms of nationalism, xenophobia, communal irredentism is present. ${ }^{25}$

\footnotetext{
${ }^{23}$ For more details see: BAJROVIC, Reuf, GARCEVIC, Vesko and Richard, KRAEMER. 2018. Hanging by a Thread: Russia's Strategy of Destabilization in Montenegro, Russia Foreign Policy Papers, Foreign Policy Research Institute. Available at: https: //bit.ly/2UrB6MY

${ }^{24}$ Reuters, 9. 5. 2019. Russians, opposition figures sentenced over role in 2016 Montenegro coup attempt, Available at: https://reut.rs/3dQsmrg

${ }^{25}$ This topic is very much connected to right-wing extremism and paramilitarism in the Western Balkans, see STOJAR, Richard, MAREŠ, Miroslav. Extreme-right paramilitary units in Eastern
} 
The main point of that in the case of Montenegro is the division of society (and politics) based on the national level, where almost one half of the population considered themselves being Montenegrins and roughly one third of the population identified themselves as Serbs. ${ }^{26}$ This is also reflected in different political orientation to the West or Serbia and the East in general of different parts of political representation of the country. Group Grievance is defined as divisions and schisms between different groups in society - particularly divisions based on social or political characteristics - and their role in access to services or resources, and inclusion in the political process. Group grievance may also have a historical component, where aggrieved communal groups cite injustices of the past. ${ }^{27}$ In the modern Montenegrin history, there are some crucial breakpoints causing group grievance and cleavages in the society - the conflict in former Yugoslavia in the first half of the 1990s, a referendum over the declaration of Montenegrin independence on Serbia (Yugoslavia, since 2003 Serbia and Montenegro) held in 2006, and political orientation of the government toward the West, with a view of joining NATO (2017) and EU in the future. Although it is difficult to define and identify it, there is an important group of Montenegrin citizens feeling grievance from these breakpoints that have brought their country to a state they are not comfortable with. The Montenegrin separation from Serbia was decided by $55 \%$ of citizens voting for it while $45 \%$ were against. ${ }^{28}$ A relevant part of Montenegrin society still keeps their Serbian identity and prefers the political orientation to Beograd or Moscow rather than Brussels.

These two indicators are raising the chance of a coup attempt while providing the environment for possible popular support (if needed), the dissatisfaction of certain part of the state's citizens with the government and weakening of the government's legitimacy. The third indicator - External Intervention - is the indicator able to multiply the previous two. This indicator considers the influence and impact of external actors in the - particularly security and economic - functioning of a state. On the one hand, the indicator focuses on security aspects of engagement by external actors, both covert and overt, in the internal affairs of a state at risk by governments, armies, intelligence services, identity groups, or other entities that may affect the balance of power (or a conflict resolution) within a state. On the other hand, External Intervention also focuses on economic engagement by outside actors, including multilateral organizations. In the case of Montenegro and the coup attempt, the court confirmed the direct involvement of foreign agents in the affair. The Russian influence in the Montenegrin politics and economy has been very strong for more than two decades. By using the Orthodox church, successfully shaping pan-Slavic attitudes and supporting

Europe. In: Mapping the extreme right in contemporary Europe. London and New York: Routledge, Londýn, 2012, p. 159-172. ISBN 978-0-415-50265-8

${ }^{26}$ The proportion between Montenegrins and Serbs has been changing since the independence declaration in 2006. Number of people declaring their Serbian nationality declines as more and more citizens accept their Montenegrin identity. Plus, there are also other nationalities in the country - Bosniaks, Albanians and Croats. For detailed information, see the population census 2011, available at: https://bit.ly/2UrSdxS

${ }^{27}$ For further information see STOJAR, Richard, STOJAROVÁ, Věra. Balkan Regional Development: Moderate or Radical Islam for the Balkans. Journal of Balkan and Near Eastern Studies, 2019, 21(4), 387-402. ISSN 1944-8953.

28 BBC, 23 May 2006, Montenegro vote result confirmed, available at: https://bbc.in/3f74nnS 
the pro-Russian political opposition, Kremlin raises the rating of the External Involvement indicator without its military presence in the territory. ${ }^{29}$ On the other hand, pan-Slavism is something tricky in the case of Montenegro. Some experts say it is more based on historical events and Montenegrin experience than emotional and irrational sympathy toward Russians and Slavs in general. Historically, Russia has played the role of the protector of the region from the Turks. ${ }^{30}$ Nowadays, the sympathy is based more on the Russian support of the Montenegrin economy by Russian investments.

The regime type in the case of Montenegro can be a tricky thing concerning the political system and reality in the country. According to The Economist, the Democracy Index is (now and in 2016 as well) around the score 5.6, where 10 is the maximum of democracy and 1 is a pure authoritarian regime. According to this ranking, the Montenegrin system is somewhere in the middle, labelled as a hybrid regime; nor democracy, nor dictatorship. ${ }^{31}$ Therefore, in the Montenegrin case, it is impossible to strictly use the indicator, it is better to focus on governmental and civil society strength.

Just like in the case of government, we can use an independent monitoring and ranking service to follow the civil society strength. The widely used Civil Society Index (CSI) developed by CIVICUS, a global alliance of civil society organizations and activists, can be very fruitful for it. The indexing system works with five levels of civil society in the countries. Montenegro has been receiving the score "Narrowed", the second best from five. ${ }^{32}$ The organization defines the narrowed rating as a condition where a state allows individuals and civil society organizations to exercise their rights to freedom of association, peaceful assembly and expression. Still, violations of these rights also take place. Protests are conducted peacefully, although authorities sometimes deny permission, citing security concerns, and excessive force, which may include tear gas and rubber bullets, are sometimes used against peaceful demonstrators. The media is free to disseminate a wide range of information, although the state undermines complete press freedom either through strict regulation or by exerting political pressure on media owners. ${ }^{33}$ The real situation of Montenegro undoubtfully fits into this score definition. It means that the civil society in Montenegro is not as strong as it is in many European democracies, but it is still at a high level compared to the majority of the world. Therefore, the real strength is high, which limits the probability of coup attempts and chances of such efforts to succeed.

Planning the coup on the eve of the elections confirms the election indicator warns us about a higher risk of a coup attempt during the election time. The effort to topple the government right at the time of the election in Montenegro is a perfect example of the relevance of this indicator. On the other hand, there had not been ant history of coup

${ }^{29}$ CONLEY, Heather and Matthew Melino. 2019. Russian Malign Influence in Montenegro: The Weaponization and Exploitation of History, Religion, and Economics, Center for Strategic and International Studies, Available at: https://bit.ly/2UwbJtd

30 DJILAS, Aleksa. 1991. The Contested Country: Yugoslav Unity and Communist Revolution, 1919-

53, Cambridge: Harvard University Press, ISBN-13: 978-0674166981, p. 28.

31 Data and graphics available at: https: / /bit.ly/3cOVOfZ

32 CIVICUS. State of Civil Society Report 2017, Available at: https://bit.ly/3fdmM2z

${ }^{33}$ CIVICUS. Monitor: Tracking Civic Space. Ratings, Available at: https://bit.ly/2AVnEtP 
attempts in the Montenegrin past. There is a question whether this attempt would affect the possibility of any other effort in the future - both ways.

So, now we are getting to the economy as an essential factor of social satisfaction with the government's performance. After the breakup of the Eastern bloc, the fall of communism and disintegration of Yugoslavia, the Montenegrin economy had to transform to the market-oriented type. Like anywhere else, the economic transformation was painful for the local industry and old structures of the economy. It also helped financial sharks and organized crime structures to increase their power over the country. On the other hand, the economy of Montenegro has been in good shape for the last decade, mainly due to foreign investment and tourism. If we look at the data and the GDP per capita rating, the Montenegrin position in the chart is quite good compared to other countries of the region; better than Bosnia and Herzegovina, Serbia, Northern Macedonia, Albania, and Kosovo, but worse than Croatia. ${ }^{34}$ Thus, from the perspective of macro-economy, the Montenegrin position in the chart and economic performance is relatively good.

On the other hand, from the perspective of economic freedom affecting any individual at the level of micro-economy, Montenegro is obtaining the $91^{\text {st }}$ position out of 180 (higher number means less freedom) according to the Economic Freedom Index. ${ }^{35}$ This classification labels the Montenegrin economy as "Moderately Free" and puts the country below any other state of the region in the ranking. Heritage.org explains it by a very high level of corruption and nepotism within the system. Plus, Montenegro's long-term political stability remains uncertain. Political tensions might be fuelled in part by the discontent with the corruption, weak rule of law, and limited media freedom. The same concerns hold back greater economic freedom. ${ }^{36}$ But the political system has been proving its high stability so far. Presence of Milo Dukanović in the positions of president or prime minister, leading and ruling the country, has been essential in this respect. With him holding the power, the semi-authoritarian regime in Montenegro is constant and changeless. But dissatisfaction with the state of economic freedom could raise the pressure on the government from the bottom, which might lead to a higher risk of a coup attempt. Although the macro-economic situation in the country is not that bad and should not motivate putschists to use it as the argument for legitimizing a coup, the environment of corruption and nepotism, limiting the economic freedom, causes dissatisfaction among the Montenegrins. This might be the indicator of a higher risk of a coup d'etat.

The last but not least indicator is the relation between the government and the armed forces with a special attention to defence expenditure. There is a need to look at the government's spending on the military over a broader period. Since 2010, there was a noticeable decrease in military spending from 72 million dollars to 56 million in 2013. 2013 was the bottom in expenditure, but in 2014 and 2015, the amount of money flowing into the military raised very slowly to 59 million dollars each year. Since 2016, there has been a noticeable growth of expenses; 64 million in 2016, 65 million in 2017

\footnotetext{
${ }^{34}$ See and compare at International Monetary Fund, World Economic Outlook Database, October 2019, available at: https://1url.cz/9zilg

${ }^{35}$ Heritage.org, Economic Freedom Index: Country Rankings, available at:

https: / /herit.ag/3e1kZx2

${ }^{36}$ Heritage.org, Economic Freedom Index: Montenegro, available at: https://herit.ag/2znGvxa
} 
and 77 million in 2018. ${ }^{37}$ The reason for the increase is evident, the upcoming NATO membership. Montenegro became the $29^{\text {th }}$ full-fledged member of the alliance on $5^{\text {th }}$ June 2017. Under NATO regulations, Montenegro is required to increase its defence spending to meet the $2 \%$ target of the country's GDP. The inherited excessive military infrastructure (the Ministry of Defence currently manages 256 military complexes - sites) and a high number of unpromising mobile assets require significant financial means and additional engagement of staff. ${ }^{38}$

Thus, if we look at the issue from the perspective of a coup attempt indicators, the period from 2013 to 2015 might be seen a bit risky. But the rise of the government's attention to the armed forces with the upcoming accession to NATO also meant the increase in military budget, modernization and recruitment. From this perspective, the armed forces should be satisfied, at least in matters of economy. The decision of entering NATO should ease the tension within military forces with the promise of upcoming development and expenditure raise. On the other hand, the part of the Montenegrin forces which represent the part of society oriented more toward Serbia and Russia rather than the West might be dissatisfied with the move. It might be the reason for a higher coup risk, but the satisfaction of the majority of the armed forces with the rise of investments seems to be the more decisive factor. Although the background and situation in 2013 to 2015 might be considered a positive indication of a higher probability of a coup attempt, the shift of government policy toward the armed forces may result in the exclusion of the examined indicator.

\section{CONCLUSION}

The EWS for a coup d'état can be a useful tool for observing and following the probability of a coup attempt in an examined country or territory. The set of indicators provided above can provide an overview of the situation that might tend to topple the government. The set can be used for a long-term situation monitoring and basic evaluation. Some indicators can be quantified due to indexing services such as the Fragile State Index, Economic Freedom Index, etc. Some indicators need a purely qualitative approach based on the knowledge and experience of the evaluator.

The case study of the Montenegro coup attempt shows the indicator set can be used at three different levels: 1) the general EWS of a coup d'état to analyze the situation in and orientation of the society, politics and military that might tend to overthrow an ineffective government, 2) the estimation of success of a potential coup attempt, whether it is more likely to succeed or fail according to the examined conditions, 3 ) the long term analysis of the development of indicators for coup prediction or prevention.

The coup attempt in Montenegro in 2016 shows some indicators were positive during the period and confirms their presence could influence the probability of a coup attempt. The essential indicators seem to be the presence (and the involvement) of foreign security personnel, the period of parliamentary elections with the shift of the

37 Trading Economics, Montenegro Military Expenditure: 2005-2018 Data, available at: https: / /bit.ly/2BM7sLG

${ }^{38}$ GlobalSecurity.org, Montenegro - Military Spending, available at: https: //bit.ly/2UwOCyR 
government toward joining NATO. As supportive elements, we can mention the weaker civil society, lower governmental legitimacy due to the high level of corruption and nepotism, and limited economic freedom. The indicators of macro-economy, regime type and history of coup attempts were not confirmed in the case of Montenegro in 2016. Whereas the armed forces did not participate in the coup attempt and their position and financing were supposed to be improved on the background of the NATO joining process, we can exclude this indicator as well. The combination of confirming and excluding indicators shows that the situation and condition were sufficient for a coup attempt, but not for its success in toppling the government.

There is another perspective to be mention at the end. As anywhere else in the Balkans, there are many unclear issues and theories about the reality of the coup attempt in 2016. Milo Djukanović is an authoritarian leader of the country and very soon after the announcement of suppressing the coup attempt, the discussion about the trustworthiness of the state declaration and trial have appeared. Some say it was just a manoeuvre of Djukanović to eliminate his political opponents and secure his winning in the elections. ${ }^{39}$ It is fair to point out this perspective as well, while it might affect the outcome of the article being based on an official version of the coup attempt story.

${ }^{39}$ East and West. 2017. Was the Montenegro coup "fake news"?, available at: https://bit.ly/3dW6dlg 
